\title{
Palliative forløp kan gjøres bedre
}

Tiltak som kreftkoordinator og pakkeforløp skal hjelpe pas ienter i palliativ fase. Men det svikter i samhandlingen mellom sykehus og kommune.

\section{Forfattere}

\section{Martha Høvik}

Onkologisk sykepleier

Sykehuset Innlandet HF, Lillehammer

\section{Simone Kienlin}

Rådgiver

Sykehuset Innlandet HF, Lillehammer

\section{Geir Vegar Berg}

Forskningsveileder og førsteamanuensis

Sykehuset Innlandet HF, Lillehammer og Norges teknisk-vitenskapelige universitet, Gjøvik

\section{Nøkkelord}

Palliasjon Pasientforløp Dialog Samhandling

\section{HOVEDBUDSKAP}

Den palliative fasen kjennetegnes ved et komplekst sykdomsbilde. I tillegg til den aktuelle sykdommen kan pasienten ha andre plager som akutte tilstander, tap av fysiske funksjoner, økt hjelpebehov eller annet som krever rask vurdering. Samhandling mellom spesialisthelsetjenesten, primærhelsetjenesten og den enkelte pasienten kan i mange tilfeller være utfordrende for dem som skal utføre hjelpe- og støttefunksjoner.

Målet med all palliasjon er å oppnå best mulig livskvalitet for pasienten og dens pårørende gjennom lindring av symptomer og plager (1). Mennesker i palliativ fase grunnet kreft eller annen langtkommen sykdom vil vekselvis ha behov for tilbud både fra kommune og spesialisthelsetjenesten (2).

Stortingsmelding 47 (2008-2009) «Samhandlingsreformen: Rett behandling - på rett sted - til rett tid» ble behandlet og vedtatt av Stortinget våren 2010 (3). Intensjonene i samhandlingsreformen er å sikre bærekraftig, helhetlig og sammenhengende tjenestetilbud av god kvalitet, med høy pasientsikkerhet og tilpasset den enkelte bruker. Videre legges det også føringer for mer folkehelsearbeid, behandling, oppfølging og rehabilitering i kommunene. Pasientene kommer tidligere tilbake til hjemkommunen, noe som krever mer kommunikasjon mellom ulike faggrupper og koordinerte tjenester.

\section{Eksisterende tiltak}

De siste årene har mange kommuner hatt egne kreftkoordinatorer. Kreftforeningen har slike koordinatorer som et satsingsområde og gir økonomisk støtte til flere kommuner for å opprette eller drifte koordinatorstillingene. Intensjonen har vært å bedre kreftpasienters livskvalitet der de bor (4). Kreftkoordinatorene skal være synlige og lett tilgjengelige lokalt, både for kreftpasienter og deres pårørende. De skal ha oversikt over relevante tilbud og tjenester knyttet til ulike diagnoser, rehabilitering og palliativ omsorg. Videre skal de kunne veilede og gi råd (4).

Nasjonalt handlingsprogram for palliasjon (5) omfatter blant annet kjennetegn og utfordringer ved palliasjon, faglige retningslinjer samt anbefalinger for organisering og kompetanse. Hensikten med handlingsprogrammet er å bedre den palliative omsorgen totalt og få god og lik behandling i hele landet (5). 
I 2015 ble pakkeforløpene for kreft innført. Pakkeforløpene er nasjonale faglige og normgivende standarder for pasientforløp. Eksisterende retningslinjer og plikter bygget på gjeldende lover og forskrifter gjelder fortsatt både for helsepersonell og pasienter (6).

Innføring av pakkeforløpene skal bedre samhandling innad i spesialisthelsetjenesten og mellom fastlege og sykehus. Denne samhandlingen skal gi pasientene trygghet og oversikt gjennom forløpet med informasjon og pasientmedvirkning (7).

\section{«Forløpskoordinatoren har definerte oppgaver og nødvendig autoritet til å lose pasienten gjennom systemet.»}

Et viktig tiltak i pakkeforløpene er tilsetting av forløpskoordinator ved alle avdelinger som utreder og behandler kreft. Forløpskoordinatoren har definerte oppgaver og nødvendig autoritet til å lose pasienten gjennom systemet, noe som innebærer samarbeid med de ulike involverte fagpersonene. Arbeidet omfatter også å sikre at forløpstider følges, og at kontroller og oppfølging ivaretas. Pasienters opplevelse av sykdom er individuell og samsvarer ikke alltid med funn og vurderinger (8).

\section{Prosjektets hensikt}

Prosjektet vårt er et utviklingsarbeid der tre forskere har hatt samtaler med alvorlig syke pasienter og deres pårørende i palliativ fase i livet. Hensikten med prosjektet var å få frem pasienters og pårørendes opplevelser og tanker om samhandling mellom ulike faginstanser gjennom den palliative fasen. Målet er å se på hvordan samhandlingen kan optimaliseres for å sikre kvalitet på tjenestene som utøves.

\section{Problemstilling}

Vi ønsket å finne svar på følgende spørsmål:

- Hva er det gode pasientforløpet for kreftpasienter i en palliativ fase?

- Hvilken betydning har en koordinator for samhandlingen mellom de ulike offentlige instansene og pasientene i det gode pasientforløpet?

\section{Metode}

Vi har gjennomført prosjektet med en todelt datainnsamling bestående av kvalitative data og kvantitative data, som først er analysert hver for seg, men avslutningsvis sett i en sammenheng (9). Vi innhentet de kvalitative dataene gjennom dialogsamtaler med pasienter og pårørende i ulike faser av det palliative forløpet. Hensikten med dialogsamtalene var å forstå situasjonen de var i ved å lytte og spørre for å få innsikt i situasjonen deres.

Vi brukte kvantitativ metode for å svare på en antakelse om at det er behov for kreftkoordinator til alle kreftpasienter. Vi benyttet et enkelt spørreskjema med sju spørsmål med svaralternativene «ja», «nei» eller «vet ikke». Spørsmålene var rettet mot pasienters behov og nytte av å ha kreftsykepleier eller kreftkontakt i hjemkommunen eller når de var på sykehuset.

\section{Datasamling og kontekst}

Først foretok vi spørreundersøkelsen blant kreftpasienter som fikk behandling i kreftpoliklinikker. Hensikten med undersøkelsen var å kartlegge kreftpasienters ønsker og behov for kreftkoordinator ute i kommunene og innad i sykehusavdelingene.

Senere gjennomførte vi dialogsamtalene med 22 pasienter og pårørende. Hensikten var å få frem hva respondentene opplevde som det gode palliative forløpet. Flere av pasientene i studien var gått fra aktiv til palliativ behandling og trengte hjelp til å mestre den nye, utfordrende livssituasjonen.

Respondentenes kjønnsfordeling i dialogene var lik. Aldersgruppen for menn var fra 37 til 80 år, der gjennomsnittet var 70 år. For kvinnene var alderen fra 45 til 89 år, med gjennomsnitt på i overkant av 58 år. Ti av respondentene døde i løpet av ett år. Fem hadde en rask sykdomsprogresjon, der det kun gikk måneder fra diagnosen ble stilt, til døden inntraff. De andre fem hadde hatt sykdom og blitt behandlet i over ett år. 


\section{Etiske overveielser}

I den kvalitative delen ble informantene informert, og frivillig skriftlig informert samtykke ble innhentet før dialogstart. Dialogene ble behandlet konfidensielt, og respondentene er anonymisert i skriftlig fremstilling av materialet. Vi benyttet et spørreskjema godkjent av Norsk samfunnsvitenskapelig datatjeneste (NSD) for å teste ut antakelsen om behov for kreftkoordinatorer.

\section{Resultater}

I hovedtrekk viser analysen av dialogsamtalene at det gode palliative forløpet påvirkes av flere faktorer. Spørreskjemaet viser ikke noe entydig svar på behovet for kreftkoordinator.

75 kreftpasienter svarte på spørreundersøkelsen: 50 kvinner og 23 menn, mens to ikke oppga hvilket kjønn de hadde. Ti av respondentene var i alderen 30-50 år, 38 i

aldersgruppen 51-70 år, og 27 var over 70 år. Respondentene ble spurt om behov, nytte og ønske om kontakt med kreftsykepleier eller kreftkontakt (tabell 1).

\begin{tabular}{|c|c|c|c|c|c|c|}
\hline & $\begin{array}{l}\text { Hvor finnes informasjon om } \\
\text { kreftsykepleier i kommunene? }\end{array}$ & $\begin{array}{l}\emptyset \text { nsket kontakt } \\
\text { med kreftsykepleier }\end{array}$ & $\begin{array}{l}\text { Fått tilbud om } \\
\text { kreftkontakt }\end{array}$ & $\begin{array}{l}\text { Hadde kontakt } \\
\text { med kreftsykepleier }\end{array}$ & $\begin{array}{l}\text { Hadde } \\
\text { hjemmetjeneste }\end{array}$ & $\begin{array}{l}\text { Hvordan skal } \\
\text { kontakt formidles? }\end{array}$ \\
\hline Ja & $n=29(38,7 \%)$ & $n=23(30,7 \%)$ & $n=22(29,3 \%)$ & $n=21(28 \%)$ & $n=12(16 \%)$ & \\
\hline Nei & $n=43(57,3 \%)$ & $n=28(37,3 \%)$ & $n=41(54 \%)$ & $n=53(70,7 \%)$ & $n=62(82,7 \%)$ & \\
\hline Vet ikke & & $n=21(26 \%)$ & & & & \\
\hline Tar kontakt selv & & & & & & $n=48(64 \%)$ \\
\hline $\begin{array}{l}\text { Personalet skal } \\
\text { formidle kontakt }\end{array}$ & & & & & & $\mathrm{n}=14(18,7 \%)$ \\
\hline $\begin{array}{l}\text { Svarte ikke på } \\
\text { spørsmålet }\end{array}$ & & & $n=7(9,3 \%)$ & $n=1$ & & $n=13(17,3 \%)$ \\
\hline
\end{tabular}

\section{Dialogsamtalene}

Gjennom analysen av dialogsamtalene trådte tre temaer frem da vi spurte om hva som hadde fungert bra, og hva som hadde fungert mindre bra: 1) ønske om å få være hjemme, 2) ønske om kontakt med kreftkoordinator og 3) egen planlegging av palliativ fase.

1. Ønske om å få være hjemme:

De aller fleste respondentene ønsket at pasientene skulle være hjemme selv om de var alvorlig syke og hadde begrenset kapasitet til å klare seg selv. Etter et lengre og sammensatt rehabiliteringsopphold sa en pasient at «målet var å komme hjem, neste mål er å bli enda bedre, men jeg vet hva som ligger bak og lurer».

\section{2. Ønske om kontakt med kreftkoordinator:}

Flere respondenter beskrev hvordan de hadde fått god hjelp og støtte av kreftkoordinator, palliativt team og prest. Andre sa at de ville greie seg sjøl. En pasient som opplevde en stor krise underveis i behandlingsforløpet, uttalte følgende: «Samtale med palliativt team var nyttig og gjorde godt.»

\section{三 «Pasienten måtte være sin egen koordinator, og det tok på kreftene.»}

En annen pasient fortalte at han hadde hatt kontakt med kreftkoordinator, men at det var pause i kontakten nå, men uttalte: «Jeg regner med at hun kommer tilbake nå som jeg er blitt syk igjen.» En annen respondent fortalte at kreftkoordinator ikke holdt det hun lovet: «Hun ringte ikke opp igjen.» Pasienten måtte være sin egen koordinator, og det tok på kreftene. Denne pasienten følte livet ble satt på vent.

3. Egen planlegging av palliativ fase: 
En pasient sa at når tiden var inne, var institusjonsopphold det eneste riktige.

Respondenten begrunnet det med at hun ikke ville være en belastning for familien.

Flere mente at det var godt å vite om at det fantes tilbud om opphold på sykehjem den siste tiden, - de snakket da ut ifra erfaringer fra korttidsopphold tidligere i

sykdomsforløpet. En respondent orket ikke å ta stilling til hvordan livet skulle avsluttes.

En annen sa følgende: «Jeg går litt i den trua at jeg skal bli frisk igjen.»

\section{Diskusjon}

Begrepet «palliasjon» forbindes ofte med en kortvarig lindring i livets sluttfase, der behandling, pleie og omsorg er det sentrale. Den palliative fasen kjennetegnes ved et komplekst sykdomsbilde på grunn av den aktuelle sykdommen, men også andre plager kan virke inn. Symptombildet kan vise seg gjennom akutte tilstander som tap av fysiske funksjoner og økt hjelpebehov. I dialogsamtalene spurte vi pasientene om hva som har fungert bra og mindre bra i den palliative fasen samt hvordan de planlegger avslutning eller palliativ behandling.

\section{Ønsket å være hjemme}

I dialogene med pasientene som har vært innlagt i sykehus, ga de uttrykk for at det var en utfordring å tenke på hva som skulle skje videre. Følgende sitat kan illustrere dette: «Jeg har det trygt og godt her på sykehuset, men jeg må komme meg videre, aller helst hjem.»

En annen pasient uttrykte stor tilfredshet med å være i sitt eget hjem selv med hjelp fra andre. Hun likte dårlig å tenke på at hun måtte over på institusjon hvis hun skulle bli mer hjelpetrengende.

\section{«De fleste pasientene ønsket å få være hjemme selv om de var syke og hjelpetrengende.»}

Hva betyr det å få være hjemme for en pasient med langtkommen sykdom? De fleste pasientene ønsket å få være hjemme selv om de var syke og hjelpetrengende. 15 respondenter bodde sammen med noen, mens sju bodde alene, noe som også ble bekreftet i spørreundersøkelsen. Funn fra dialogsamtalene viser at de som bor alene, tar del i planleggingen av livet «her og nå» og iverksetter nødvendige tiltak. Det betyr at aleneboende pasienter i større grad må ta ansvar selv.

De pårørende ønsket også at den syke skulle få være hjemme den siste tiden, men det viste seg å være vanskeligere å få til. De som ønsket å være hjemme den siste tiden, og som hadde pårørende rundt seg, hadde tilsynelatende gode ytre ressurser. Samtidig fremgikk det at de pårørende påtok seg en stor oppgave de ikke følte seg komfortable med.

\section{Utfordringer i hjemmet}

Birkeland og Flovik (10) hevder omsorgsoppgavene kan være mer omfattende enn først antatt samt at det kreves mye av pårørende når en person ønsker å tilbringe siste tiden av livet i hjemmet. Pårørende vil møte utfordringer der evner og kompetanse blir satt på prøve. Enkelte pårørende vil føle seg forpliktet til å ta på seg omsorgsrollen - rett og slett føle at de ikke har noe valg (11). En av respondentene sa følgende:

«Vi har ikke nok kunnskap til å ta det medisinske ansvaret for pasienten, vi vil så gjerne, men innser at dette greier vi ikke alene.»

Pårørende kan ses på som «skjulte pasienter» (11), da de er disponerte for depresjon og angst. Omsorgsbyrden kan videre føre til utmattelse og tretthet hos den pårørende (10). En slik situasjon kan dermed bli et paradoks, da palliativ omsorg har som mål å forbedre livskvaliteten til pasient og pårørende, samtidig som den pårørendes evner og kompetanse ikke strekker til (10). 
Andre pasienter uttrykte håp om å leve i mange år, selv med dårlig prognose. De fortalte om planer med å utbedre bolig eller et ønske om å delta i familiebegivenheter, ferieturer og liknende. Nielsen og Sørensen (12) beskriver hvordan det døende mennesket forholdt seg til fortid, nåtid og fremtid. Uavklarte forhold fra fortiden ble avrundet, og fremtiden ble planlagt med og fortalt til de nærmeste, slik at nåtiden kunne leves intenst og tilstedeværende. På den andre siden kan aleneboende pasienter møte andre utfordringer. En del pasienter bor alene og har levd et liv uavhengig av andre. Dermed kan det være en utfordring for disse personene å bli anbefalt å ta imot hjelp fra hjemmesykepleien når de blir syke.

\section{«Kreftkoordinator er gull verdt.»}

\section{Pårørende}

En pårørende uttrykte som følger:

«Kreftkoordinator er gull verdt. Viktig med et telefonnummer der en kan nå en person som kjenner pasienthistorien, og som kan være med og løse oppgavene når problemene oppstår.»

En annen pårørende fortalte at kreftkoordinator gjorde en fantastisk jobb i den palliative fasen.

\section{Dagens praksis}

Innføring av pakkeforløp i kreftbehandlingen medførte at alle pasienter skulle bli tildelt en forløpskoordinator allerede under utredningen når det var mistanke om kreftsykdom. I en rapport beskriver Nasjonalt kunnskapssenter for helsetjenesten at effekten av koordinering av tiltak for kreftpasienter i kommunene vil øke pasientens livskvalitet (13). Rapporten peker på at spesialutdannete kreftsykepleiere kan gi en slik koordinert tjeneste basert på kompetanse og faglig vurdering.

I studien vår beskrev pårørende kreftkoordinatorene som en kjemperessurs, og de uttrykte en takknemlighet for at kreftkoordinatoren tok tak i problemstillinger de selv hadde erfart. Pårørende fortalte at kreftkoordinator viste vilje og innsikt til å samhandle på ulike nivåer i det offentlige tjenestetilbudet, noe som samsvarer med funn hos Bjerkan og Skuldal (13). Noen pasienter uttrykte at de hadde god nytte av palliativt team, og noen av enkelttilbud. Andre hadde utbytte av koordinerte tjenester mellom palliativt team innad i sykehuset og kreftkoordinator ute i kommunen.

Andre pasienter og pårørende sa at de hadde fått tilbud om kreftkoordinator, men valgte å løse oppgavene selv da problemstillingene oppsto, noe som også kom frem i spørreundersøkelsen vår. Det var uventet at så mange ikke ønsket kontakt med kreftsykepleieren eller kreftkontakten i sin kommune. Noen pårørende var kritiske til hjemmesykepleien i sin kommune og beskrev sviktende rutiner og systemer. Det ble også rettet tydelig kritikk mot koordineringen mellom spesialisthelsetjenesten og kommunehelsetjenesten. Fastlegens rolle oppfattes å være «enten eller»: Noen pasienter og pårørende sa at de hadde tett og god oppfølging av fastlegen. Andre uttrykte at de fikk tett oppfølging da de var under behandling på sykehus, eller da de var på hospice, og derfor hadde de liten eller ingen kontakt med fastlegen.

\section{Noe fungerte mindre bra}

Spørsmålet om hva som har fungert mindre bra, ga ingen entydige svar, men pårørende beskrev at kvaliteten på system og struktur i den palliative prosessen varierte mye. Oftest var det pårørende som uttalte seg, men noen pasienter klarte å si noe om den palliative omsorgen, selv om de var svært syke.

En av de pårørende svarte at de påtok seg for stort ansvar for en alvorlig syk pasient. Denne pasienten ble skrevet ut fra sykehus med mye sterke medisiner som de pårørende skulle administrere og observere virkning og bivirkning av. Pårørende uttalte i ettertid at de ikke hadde nok kunnskap til å gjøre de riktige observasjonene, og ikke skulle hatt ansvaret. En annen pårørende opplevde at vedtak om rehabilitering under opphold på sykehjemmet ikke ble fulgt opp. Pårørende måtte etterspørre mål for oppholdet og opptreningen. 
En pasient sa at han ble passivisert på sykehjemmet. Han ble utskrevet fra sykehus til intermediærenhet på et sykehjem, og derfra til sykehjemmet i hjemkommunen. På sykehjemmet var de for få ansatte til å ta hånd om pasienter som trengte rehabilitering. Kommunene er gode på palliasjon, men mindre gode på rehabilitering (13). Flere av pasientene følte seg utrygge da de hadde vært innlagt i sykehjem. De fortalte om ufin oppførsel fra personalet da de ba om hjelp. De sa også at de ikke fikk hjelp da de ringte på om natten, eller de ble utsatt for trusler og sanksjoner fra pleiepersonalet på nattevakt.

Slike fortellinger kom også frem av en studie gjort av Nåden og Lohne (14). En annen pasient sa at helsepersonell har et forbedringspotensial når de møter den frustrerte og engstelige pasienten. En annen pårørende sa at hun ikke turte å reise bort en helg fordi hun var redd ektefellen skulle bli engstelig og urolig. Pårørende blir dermed mer opptatt av å hindre uønskete hendelser enn å tenke på egne behov.

\section{Planla avslutning}

Noen hadde tatt stilling til å planlegge avslutning eller palliativ behandling, mens andre ikke hadde gjort det. De fleste ønsket å være hjemme så lenge som mulig med tilrettelagte tjenester. Likevel viste det seg at de i livets sluttfase enten døde på sykehus eller sykehjem. Flere av pasientene ble gradvis dårligere og hadde i sluttfasen et kortvarig opphold på sykehjem. Noen pasienter fikk en akutt sykdomsforverring og døde på sykehus, mens to døde hjemme.

De respondentene som ikke hadde tatt stilling til palliativ behandling og pleie, ønsket ikke å planlegge noe som helst. De levde i håpet om at behandlingen skulle hjelpe, eller at sykdommen skulle stabilisere seg. Når pasienter fikk spørsmål om hva de ville ønske hvis de skulle få behov for pleie, svarte en pasient: «Det tenker jeg ikke på.» En annen sa følgende: «Den tanken liker jeg dårlig.»

Kvåle (15) hevder at ikke alle pasienter ønsker å snakke om vanskelige temaer, og at døende pasienter sliter med eksistensielle følelser (12). Flere av respondentene fortalte indirekte at deres avslutningsprosess hadde startet. De var mennesker midt i livet, og som «ryddet opp» etter seg. De hadde for eksempel avsluttet sin Facebook-konto. En annen respondent hadde samlet barna og gjort opp status, mens én planla sin egen begravelse og hadde bestilt prest.

\section{Konklusjon}

De fleste pasienter og pårørende beskrev at det palliativet forløpet hadde vært godt. De var takknemlige og hadde stor nytte av kreftkoordinator. Pårørende beskrev det gode palliative forløpet både fra et kortsiktig og langsiktig perspektiv. Ingen palliative forløp utvikler seg likt; utfordringene pasient og pårørende står overfor, er komplekse og sammensatte, og deres ytringer sier noe om svikt i system, struktur og prosess.

\section{«Ingen palliative forløp utvikler seg likt.»}

Både i samtaler og spørreundersøkelsen var det noen som takket nei til involvering fra det kommunale hjelpeapparatet. De ville klare seg selv så lenge som mulig. For noen var derfor det å kontakte kreftkoordinator en terskel de måtte trå over . Etter at de nye pakkeforløpene for kreft ble innført, kan det muligens føles lettere å ta kontakt med kreftkoordinator eller forløpskoordinator grunnet klare og tydelige retningslinjer samt rollebeskrivelser.

Innføring av pakkeforløpene har satt kreftbehandling i system når det gjelder utredning og behandling, men det gjenstår fortsatt en del i samhandlingen mellom sykehus og kommuner. Tilbudet om forløpskoordinatorer til kreftpasienter i sykehus og kreftkoordinatorer i kommunene varierer, og den ønskete effekten i henhold til rapporten fra Nasjonalt kunnskapssenter for helsetjenesten (13) blir derfor mangelfull.

\section{Referanser}


1. Verdens helseorganisasjon (WHO). Cancer pain relief and palliative care : report of a WHO expert committee. Geneve: WHO; 1990. Tilgjengelig fra: http://apps.who.int/iris/bitstream/10665/39524/1/WHO_TRS_804.pdf (nedlastet 06.08.2017).

2. NOU 2005:3. Fra stykkevis til helt - En sammenhengende helsetjeneste. Oslo: Helse- og omsorgsdepartementet; 2005.

3. St. meld. nr. 47. Samhandlingsreformen - Rett behandling - på rett sted - til rett tid. Oslo: Helse- og omsorgsdepartementet; 2009.

4. Kreftforeningen. Kreftkoordinator i kommunen. Tilgjengelig fra: https://kreftforeningen.no/rad-og-rettigheter/praktisk-hjelp/kreftkoordinator-ikommunen/ (nedlastet 06.08.2017).

5. Helsedirektoratet. Nasjonalt handlingsprogram for palliasjon i kreftomsorgen. 03/2015. Tilgjengelig fra https://helsedirektoratet.no/Lists/Publikasjoner/Attachments/918/Nasjonalt\%20handlingsprogram\%20for\%20palliasjon\%20i\%20kreftomsorg IS-2285.pdf (nedlastet 06.08.2017).

6. Helsedirektoratet. Implementering av pakkeforløp for kreft : Nasjonal plan for implementering av pakkeforløp for kreft 2014-2015. Oslo: Helsedirektoratet; 2014. Tilgjengelig fra: https://helsedirektoratet.no/Lists/Publikasjoner/Attachments/1083/IS2426-Nasjonal-plan-implementering-pakkeforlop-v2.pdf (nedlastet 06.08.2017).

7. Lov av 2. juli 1999 nr. 63 om pasient- og brukerrettigheter (pasient- og brukerrettighetsloven). Tilgjengelig fra: https://lovdata.no/dokument/NL/lov/1999-0702-63 (nedlastet 27.06.2017).

8. St. meld. nr. 34 (1996-97). Resultater og erfaringer fra regjeringens handlingsplaner for funksjonshemmede og veien videre. Oslo: Sosial- og helsedepartementet;1997.

9. Kaarbø E. Kombinerte metoder. Sykepleien Forskning 2009;4(3):244-8. Tilgjengelig fra: https://sykepleien.no/forskning/2009/10/kombinerte-metoder (nedlastet 27.06.2017).

10. Birkeland A, Flovik AM. Sykepleie i hjemmet. 2. utg. Oslo: Cappelen Damm Akademisk; 2014.

11. Hudson P, Trauer T, Kelly B, O’Connor M, Thomas K, Summers M et al. Reducing the psychological distress of family caregivers of home-based palliative care patients: short-term effects from a randomised controlled trial. Psycho-Oncology 2013;22(9):1987-93.

12. Nielsen R, Sörensen EE. Det døende menneske som livets læremester. Nordisk sygeplejeforskning 2013;3(2). s.117-29.

13. Bjerkan AM, Skudal KE, Holmboe O, Nasjonalt kunnskapssenter for helsetjenesten. Pasienterfaringer med norske sykehus : nasjonale resultater i 2013. Oslo: Nasjonalt kunnskapssenter for helsetjenesten; 2014. Tilgjengelig fra: http://www.kunnskapssenteret.no/publikasjoner/pasienterfaringer-med-norske-sykehusnasjonale-resultater-i-2012 (nedlastet 06.08.2017).

14. Nåden D, Lohne V. Uverdige forhold på norske sykehjem. Tilgjengelig fra: http://forskning.no/meninger/kronikk/2015/01/uverdige-forhold-pa-norske-sykehjem (nedlastet 06.08.2017).

15. Kvåle K. Do cancer patients always want to talk about difficult emotions? A qualitative study of cancer inpatients communication needs. European Journal of Oncology Nursing 2007;11(4):320-7. 